\title{
Spatio-temporal trend of BIRADS classification suggestive of malignancy: a national analysis of mammograms, 2013-2017
}

\author{
Nancy E. Navarro-Ruíz and Antonio Reyna-Sevilla* \\ Department of Public Health, University Center of Health Sciences, Universidad de Guadalajara, Guadalajara, Jalisco, Mexico
}

\begin{abstract}
Introduction: Promoting breast cancer $(B C)$ detection in women by means of mammography is a viable strategy to reduce the number of diagnoses at clinically advanced stages and mortality. Objectives: To describe the results reported by mammography studies in women, carried out nationally during 2013-2017, and to analyze the spatiotemporal trend of Breast Imaging Reporting and Data System (BIRADS) categories suggestive of malignancy by State. Method: Longitudinal, analytical design that included information on mammography studies of women according to age group ( 40 and $\geq 40$ ), evaluated in units of the Ministry of Health of Mexico during 2013-2017. The frequency of BIRADS categories and a standardized rate suggestive of malignancy (categories 4 and 5) were estimated in women aged $\geq 40$ years, and spatial statistics were used to analyze the trend by State. Results: A total of 3,659,151 mammograms were analyzed, $98.5 \%$ in women aged $\geq 40$ years. The malignancy-suggestive rate decreased from 38.3 (2013) to 31 (2017) per 100,000 women aged $\geq 40$ years; however, the risk of detection increased up to 13 times in ten States. Conclusions: Although the risk of detection in categories suggestive of malignancy decreased at the national level, some States need to reinforce the application of BC detection programs through mammography and increase the participation of the target population.
\end{abstract}

KEY WORDS: BIRADS. Mammography. Suspicion for malignancy. Geolocation.

\section{Tendencia espacio-temporal de clasificación BIRADS sugestiva de malignidad: un análisis nacional de mastografías, 2013-2017}

\section{Resumen}

Introducción: Promover la detección de cáncer de mama (CaMa) en mujeres mediante mastografía es una estrategia viable para disminuir los diagnósticos en fases clínicamente avanzadas y la mortalidad. Objetivos: Describir los resultados reportados por estudios de mastografía en mujeres realizados a nivel nacional durante 2013-2017 y analizar la tendencia espaciotemporal de categorías BIRADS (Breast Imaging Reporting and Data System) sugestivas de malignidad por Estado. Método: Diseño analítico longitudinal que incluyó información sobre estudios de mastografía de mujeres según grupo de edad (<40 e $\geq 40$ ), valoradas en unidades de la Secretaría de Salud, México, durante 2013-2017. Se estimó la frecuencia de categorías según BIRADS, tasa estandarizada sugestiva de malignidad (categorías 4 y 5) en mujeres $\geq 40$ años y se utilizó estadística espacial para analizar la tendencia por Estado. Resultados: Se analizaron 3,659,151 mastografías, el $98.5 \%$ en mujeres $\geq 40$ años. La tasa sugestiva de malignidad disminuyó de 38.3 (2013) a 31 (2017) por 100 mil mujeres $\geq 40$ años; sin embargo, el riesgo de detección aumentó hasta 13 veces en diez Estados. Conclusiones: Aunque el riesgo de detección en categorías sugestivas de malignidad disminuyó a nivel nacional, algunos Estados requieren reforzar la aplicación de programas de detección del CaMa mediante mastografía e incrementar la participación de la población blanco.

PALABRAS CLAVE: BIRADS. Mamografía. Sospecha de malignidad. Geolocalización.

\footnotetext{
Correspondence:

*Antonio Reyna-Sevilla

E-mail: gs.antonioreyna@gmail.com

Gac Med Mex. 2021;157:167-173

Contents available at PubMed

www.gacetamedicademexico.com

0016-3813/@ 2020 Academia Nacional de Medicina de México, A.C.. Published by Permanyer. This is an open access article under the CC BY-NC-ND license (http://creativecommons.org/licenses/by-nc-nd/4.0/).
} 


\section{Introduction}

The Breast Imaging Reporting and Data System (BIRADS) was developed by the American College of Radiology (ACR); ${ }^{1}$ it constitutes the universal language to classify findings in breast imaging investigations in order to establish the degree of breast cancer (BC) suspicion and the medical management behavior to be followed for each case. ${ }^{2}$ In this sense, mammographic examination reports a numerical classification ranging from 0 to 6 , the results of which indicate: incomplete evaluation that requires other complementary investigation (category 0 ), findings unrelated to suspicion for malignancy (categories 1 and 2), probably benign (category 3 ), suspicion for malignancy (categories 4 or 5), or malignancy already demonstrated by biopsy (category 6). ${ }^{3}$ The method that is recognized as the most cost-effective for timely detecting $B C$ is mammography, not so self-examination and clinical breast evaluation, ${ }^{4}$ since it allows timely detection of the disease at early clinical phases. and, eventually, mortality rates reduction by $20-30 \%$ in women > 50 years of age. ${ }^{5}$ However, to achieve this goal, the World Health Organization (WHO) advises that BC screening programs by mammography should reach a coverage or participation of $70 \%$ of the target population. ${ }^{6}$

In adherence to the recommendations and guidelines of the NOM-041-SSA2-2011 standard For the prevention, diagnosis, treatment, control and epidemiological surveillance of breast cancer, in Mexico, mammography screening is recommended for the entire female population aged 40 to 69 years. ${ }^{7}$ However, the National Health and Nutrition Survey (ENSANUT - Encuesta Nacional de Salud y Nutrición) reported a participation of $36 \%$ of the target population in $2012 .{ }^{8}$ More recently, the National Institute of Statistics and Geography (INEGI - Instituto Nacional de Geografía y Estadística) reported the states where a larger number of mammograms were performed in 2016: Mexico City $(29.4 \%)$, Veracruz $(6.7 \%)$ and Nuevo León $(6.3 \%)$; in contrast, Colima registered only $0.4 \% .{ }^{9}$ Thus, this panorama could explain the fact that the majority of $\mathrm{BC}$ diagnoses in Mexican women are made at clinically advanced stages, where the success of cancer treatments and possibilities of survival are considerably reduced. ${ }^{10}$

Currently, there are still only few studies published in Mexico that geographically analyze the variability and changes of the BIRADS categories reported by mammographic examinations. However, in other countries, epidemiological studies with a geographic approach have been developed to determine not only the zones where improving secondary prevention strategies through screening programs is required (which on the other hand are associated with the detection of categories with suspicion for malignancy) ${ }^{11-13}$ but it is also possible for the degree of participation of the target population and high-risk groups defined by age or place of residence to be identified. Thus, the evidence has contributed to geographically focus the improvement of strategies aimed at promoting $\mathrm{BC}$ early detection by mammography and thus eventually reduce the burden of diagnoses at clinically advanced stages, as well as mortality. ${ }^{12}$ For all the above reasons, the purposes of this study were, on one hand, to describe the results reported by mammography examinations carried out in women nationwide in the 2013-2017 five-year period and, on the other, to analyze the spatiotemporal trend, by state, of those categories with suspicion for malignancy according to the BIRADS classification.

\section{Material and methods}

Based on official data reported by the National Center for Gender Equity and Reproductive Health (CNEGSR - Centro Nacional de Equidad de Género y Salud Reprodictiva) Information System on Women's Cancer (SICAM - Sistema de Información de Cáncer de la Mujer), Breast cancer section, ${ }^{14}$ an analytical, longitudinal, geographically-focused study was carried out, where information on mammography screening carried out in women at units of the Ministry of Health distributed in the 32 States of Mexico was included. From this source, the results reported by mammography evaluations carried out in the 20132017 five-year period were obtained and thus, a first stage of the analysis consisted in determining the frequency of categories according to the BIRADS classification. $^{15}$

Given the clinical importance implied by the categories with suspicion for malignancy, emphasis was placed on those mammograms that reported BIRADS 4 and 5 in order to perform a geographic analysis based on the estimation of standardized rates by age and year. Therefore, said mammograms were georeferenced by state and classified in two groups: $<40$ years and $\geq 40$ years of age, which complied with the criteria established by the NOM-041SSA2-2011 standard regarding the recommended age 
for mammographic examination, either for screening or diagnostic purposes, ${ }^{7}$ in addition to the fact that the risk of $\mathrm{BC}$ in women exponentially increases after 40 years of age ${ }^{16}$ In the calculation of standardized rates, only mammograms that reported categories 4 and 5 (suspicion for malignancy) in women $\geq 40$ years of age were used according to state and year (numerator), as well as projections for the female population reported by the National Population Council (CONAPO - Consejo Nacional de Población) in the 20132017 period (denominator). ${ }^{17}$

Based on the above, linear regression was used to analyze the temporal trend regarding the detection of categories suspicious for malignancy in women $\geq$ 40 years of age. On the other hand, the spatial trend was examined using a map that showed the states where the risk increased or decreased when the 2017 standardized rate was compared with that recorded in 2013. Finally, the spatial interpolation technique ${ }^{18}$ was used to generate an area (model) throughout the country where, using lines, similar values associated with the standardized rate in the 2013-2017 five-year period were connected. This was done with the purpose to visualize areas where mammograms with suspicion for malignancy in women aged $\geq 40$ years could be detected at the municipal level, even when obtaining information of mammographic examinations at said territorial scale was not possible, given that one of the contributions of the spatial interpolation technique was to estimate said risk by municipality. ${ }^{18}$ Data analysis was carried out with the SPSS program, version 23 , and thematic maps were generated using QGIS, version 3.10 .

This study was classified as a risk-free investigation, according to the General Statute of Health on Health Research in Mexico. Data obtained from the public registry were managed in accordance with the ethical guidelines of the Council for International Organizations of Medical Sciences (CIOMS), guideline 22, on the use of data obtained from the online environment and digital tools in health-related research. ${ }^{19}$

\section{Results}

According to the source that was consulted to carry out the descriptive and geographical analysis, in the 2013-2017 five-year period, 3,659,151 mammograms were performed, out of which $98.5 \%(n=3,603,586)$ corresponded to women aged $\geq 40$ years (mean $[\bar{x}]=50.7$, standard deviation $[S D]=7.4)$, i.e. approximately $25 \%$ of the female population
Table 1. Relative frequency of BIRADS categories reported by mammographic examination in women by age group, Mexico 2013-2017

\begin{tabular}{l|c|c|}
\hline \multirow{2}{*}{ BIRADS categories } & \multicolumn{2}{|c|}{ Age group } \\
\cline { 2 - 3 } & $<40$ years & $\geq 40$ years \\
\hline \multirow{2}{*}{ Incomplete (0) } & 10.18 & 7.65 \\
\hline Negative (1) & 19.67 & 19.26 \\
\hline Benign (2) & 60.84 & $\overline{\mathrm{x}}=50.7 ; \mathrm{SD}=7.4$ \\
\hline Probably benign (3) & 5.77 & 67.43 \\
\hline Suspicious (4) & 2.39 & 4.64 \\
\hline $\begin{array}{l}\text { Highly suggestive of } \\
\text { malignancy (5) }\end{array}$ & 1.11 & 0.75 \\
\hline UD & 0.012 & 0.23 \\
\hline$\%$ & 1.50 & 0.0006 \\
\hline
\end{tabular}

BIRADS = Breast Imaging Reporting and Data System; $\bar{x}=$ mean; $S D=$ standard deviation; $\mathrm{UD}=$ undefined.

Created by the authors based on data reported by the National Center for Gender Equity and Reproductive Health on Women's Cancer. ${ }^{14}$

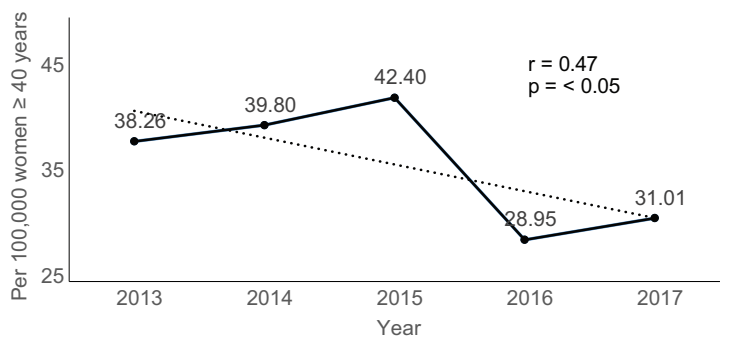

Figure 1. Trend of detection at categories suspicious for malignancy (BIRADS 4 and 5) in women aged $\geq 40$ years reported by mammographic examinations in Mexico, 2013-2017 (created by the authors based on data reported by the National Center for Equity of Gender and Reproductive Health on Women's Cancer). ${ }^{14}$ BIRADS = Breast Imaging Reporting and Data System.

(between 40 and 69 years of age) that resided in Mexico during the same period. Table 1 shows the relative frequency of the BIRADS categories reported according to age group; $86.7 \%$ of mammograms $(n=3,124,487)$ were classified as negative or benign in women aged $\geq 40$ years.

On the other hand, the probability of detection of categories with suspicion for malignancy (BIRADS 4 and 5) showed a downward trend $(p<0.05)$; nationwide standardized rate changed from 38.3 (2013) to 31 (2017) per 100,000 women aged $\geq 40$ years (Fig. 1). However, when the 2017 rate was compared 


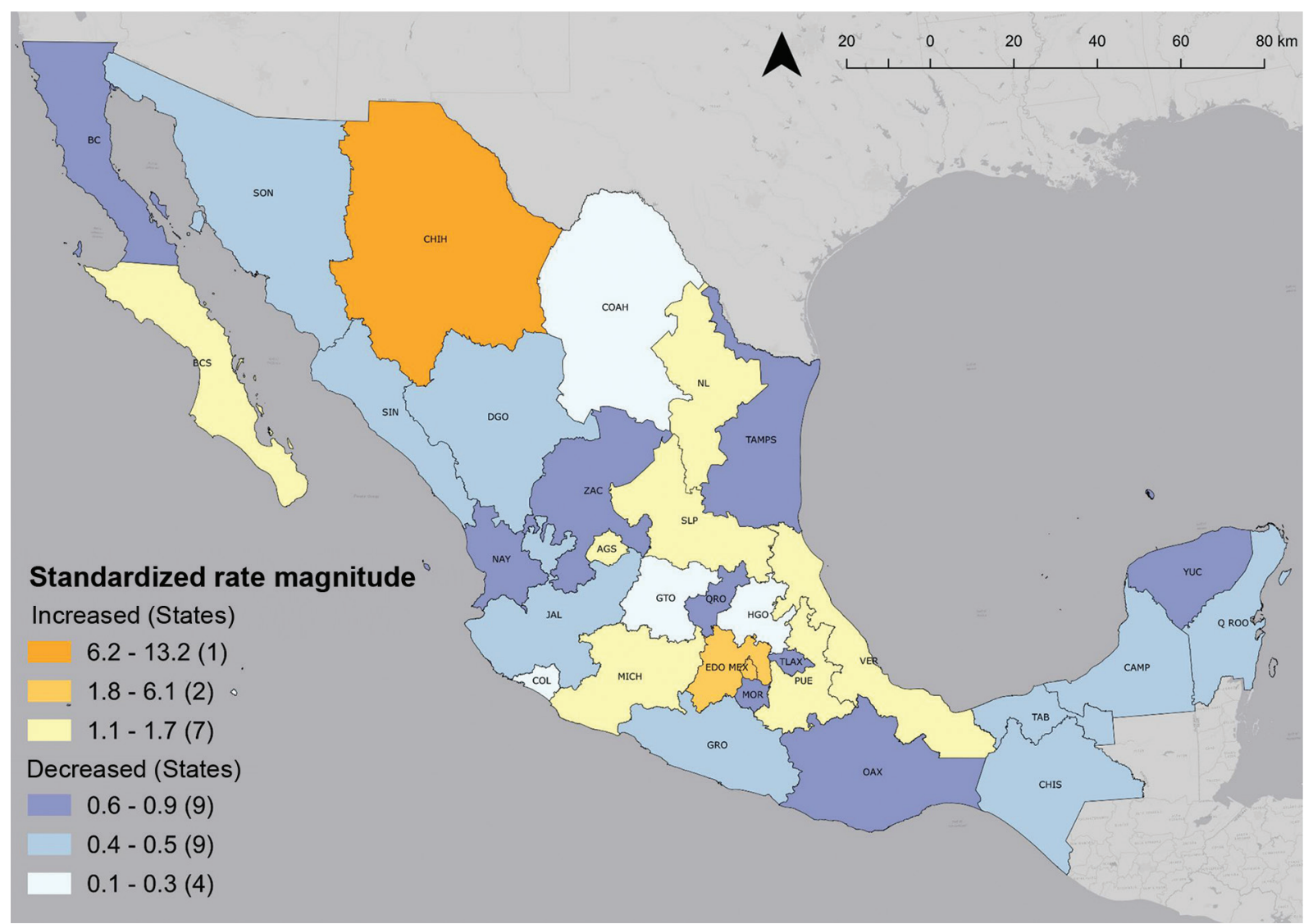

Figure 2. Standardized rate of categories with suspicion of malignancy (BIRADS 4 and 5) geographic variation in women aged $\geq 40$ years, comparison between 2013 and 2017 (created by the authors based on data reported by the National Center for Gender Equity and Reproductive Health on Women's Cancer). ${ }^{14}$ BIRADS = Breast Imaging Reporting and Data System.

with that recorded in 2013, 10 States (31.3\%) were identified, located mainly at the center and north of the country (regional pattern), where the risk of detection at categories 4 and 5 increased up to 13 times; for example, in Chihuahua, the rate changed from 5.8 (2013) to 76.1 (2017) per 100,000 women aged $\geq 40$ years, and in Mexico City, the variation was from 7.4 (2013) to 44.8 (2017) per 100,000 women aged $\geq 40$ years (Fig. 2). In addition, the States where there was a higher risk of detection with suspicion for malignancy in the five-year period were Campeche and Coahuila, the standardized rates of which were 68.3 and 76.4 per 100,000 women aged $\geq 40$ years, respectively (Fig. 3).

Regarding the spatial model represented in figure 4, two areas were identified in which, in comparison with other states, a larger number of mammograms with suspicion for malignancy could be detected; one located at the southeast of the country, which involves municipalities of Tabasco and Campeche, and another that goes from the west (Jalisco, Aguascalientes,
Guanajuato, Querétaro and Zacatecas) to the north of Mexico (Nuevo León, Coahuila and Chihuahua).

\section{Discussion}

Even when 8 out of every $10(n=3,169,229)$ mammographic examinations reported BIRADS 1 or 2 , and the trend of suspicion for malignancy detection decreased at the national level, when the 2017 standardized rate was compared with that of 2013 , the risk considerably increased in 10 States $(31.3 \%)$. Therefore, the evidence highlights the importance of continuing and improving mammography screening programs in Mexico, on one hand, because they are being used as an early detection method and not as part of diagnostic evaluation, and on the other, in some states, the risk of BIRADS 4 and 5 detection has increased up to 13 times. However, another aspect to highlight from the results is the importance of increasing the participation of women in the process of $\mathrm{BC}$ early detection. 


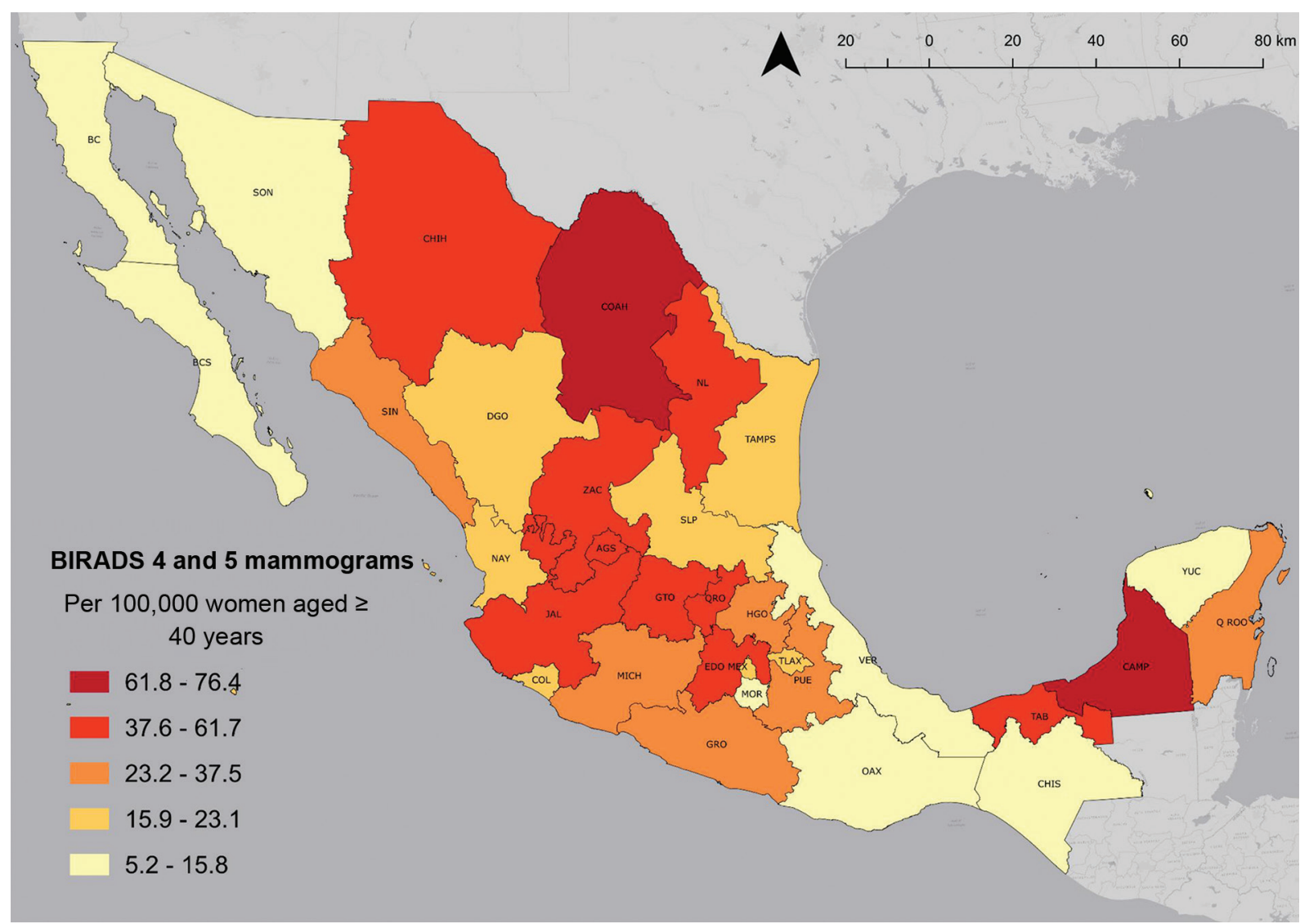

Figure 3. Standardized rate of detection at categories suspicious for malignancy (BIRADS 4 and 5) in women aged $\geq 40$ years by state, 2013-2017 (created by the authors based on data reported by the National Center for Gender Equity and Reproductive Health on Women's Cancer). ${ }^{14}$ BIRADS = Breast Imaging Reporting and Data System .

Although during the 2013-2017 five-year period there was a decrease in the probability of detection at categories with suspicion for $\mathrm{BC}$ malignancy at the national level, some states were also identified where reinforcing the strategies established by the NOM-041SSA2-2011 standard is necessary, in terms of epidemiological surveillance and timely detection. ${ }^{7}$ Indeed, Mexico City, the State of Mexico, Michoacán and Chihuahua registered a rate ranging between 42.4 and 76.1 per 100,000 women aged $\geq 40$ years in 2017 ; in addition, according to the presented spatial model, in Chihuahua, mammographic detection at BIRADS 4 and 5 categories is likely to continue (Fig. 4). Consequently, the presented evidence contributes to prioritize those states where intensifying secondary prevention is necessary by performing mammographic examinations at the population level. That would be the case of Chihuahua, which, according to statistics reported by INEGI in 2016, ${ }^{9}$ was one of the States with the highest BC mortality rate (20 and 26 per 100,000 women). Therefore, it is an alternative for reducing the number of results classified as suspicious for malignancy and diagnoses at clinically advanced stages. ${ }^{5}$

In the last 10 years, in Mexico, a limited participation of women in the performance mammograms as established by NOM-041-SSA2-2011 has been reported; ${ }^{7}$ i.e. between $11.7^{8}$ and $20 \% .^{10}$ Although there is insufficient evidence, a geographic analysis of mammographic examinations suggests that probably only $25 \%$ of the target population had a history of an examination of this nature, which exhibits a lower parameter than that recommended by the $\mathrm{WHO}$ in order to reduce BC mortality by up to $30 \% .{ }^{5}$ In this context, the identification of priority states at the country's national, central and northern levels (Fig. 2) acquires importance in order to define where not only promoting BC timely detection through mammography, as it has been done in other countries, ${ }^{11-13}$ but also increasing women participation is necessary; most mammographic evaluations have been reporting favorable results, i.e. categories 1 and 2 according to BIRADS classification. ${ }^{15}$ 


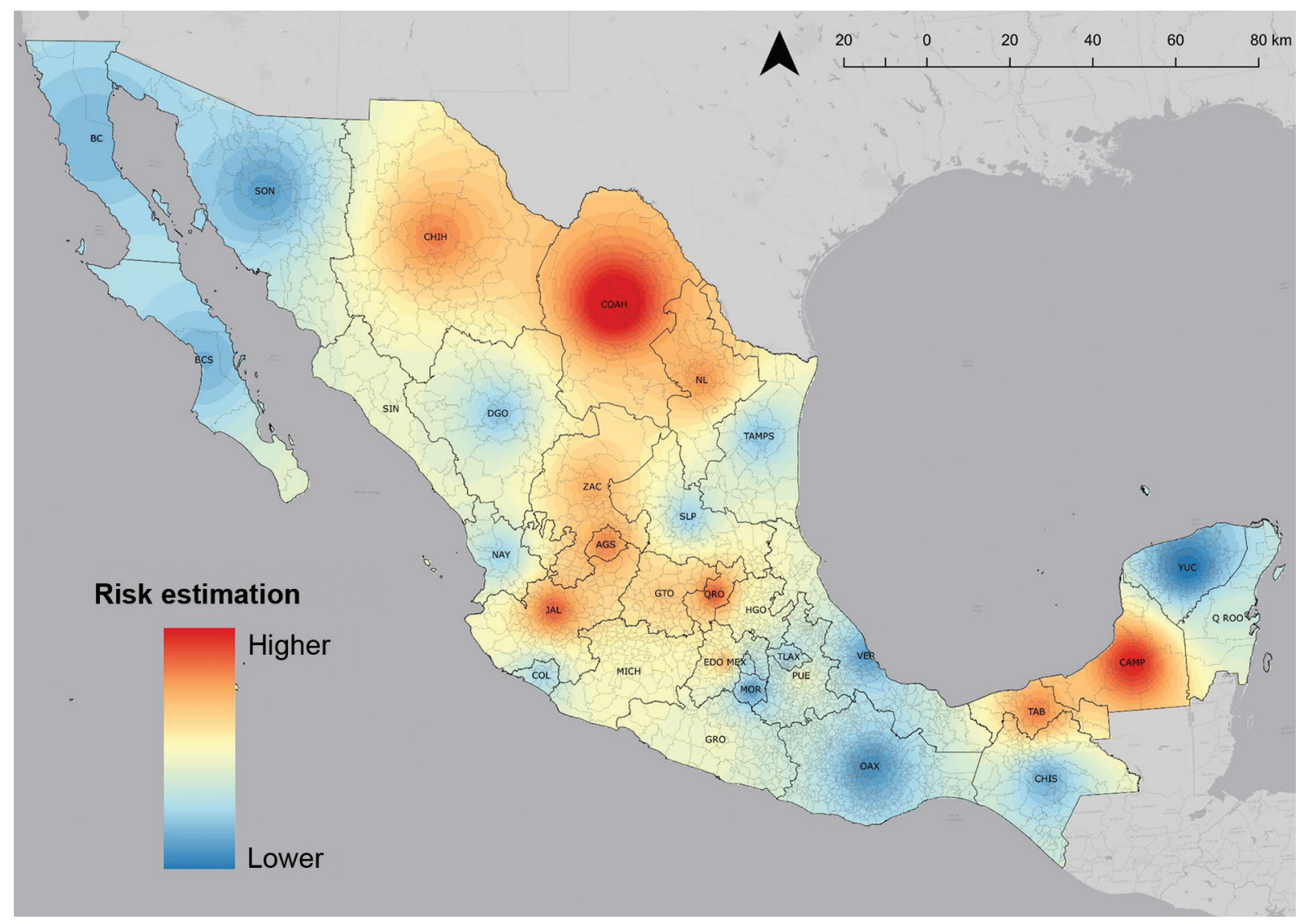

Figure 4. Spatial model for detection of mammograms at categories with suspicion for malignancy (BIRADS 4 and 5) in women aged $\geq 40$ years by municipality and State (created by the authors based on data reported by the National Center for Gender Equity and Reproductive Health on Women's Cancer). ${ }^{14}$ BIRADS = Breast Imaging Reporting and Data System .

Now, some intrinsic limitations to the presented methodological design should be mentioned. The level of territorial disaggregation that was established was by state, and this limited the spatiotemporal behavior analysis at the municipal level in order to obtain focused results. On the other hand, the database that was used did not allow to determine how many women underwent mammograms on two or more occasions within the study period; thus, this could decrease the real percentage of participation in the $\mathrm{BC}$ detection process. Neither was it reported whether mammographic examination was for screening or diagnostic purposes, as established by NOM-041SSA2-201, ${ }^{7}$ which is of special interest in the follow-up and evaluation of said process. However, there are some strengths that should be highlighted, i.e. the analysis allowed $\mathrm{BC}$ detection temporal trend (within the 2013-2017 period) and spatial behavior (considering all 32 states) to be simultaneously compared by means of mammograms, as well as to visualize a risk indicator at the municipal level. According to the authors, this study represents the most recent analysis, carried out at the national and state level, on the results reported by mammographic examinations in Mexican women; the amount of analyzed data implies a significant sample, unprecedented in studies of this nature.

In conclusion, of the total number of mammographic examinations analyzed in the 2013-2017 period, $98 \%$ were carried out in women $\geq 40$ years of age, and 8 out of every 10 reported categories 1 or 2 according to BIRADS, which is in compliance with the NOM-041SSA2-2011 standard regarding the performance of the exam in this population group and as a method for early detection. ${ }^{7]}$ However, although the proportion of States where the probability of detection at categories 4 and 5 increased was $31.3 \%$ (center and north), this implied a magnitude up to 13 times higher in 2017 with regard to 2013. 
Thus, the evidence suggests that $B C$ detection programs should be improved or strengthened with mammography (secondary prevention), mainly in States with at-risk populations or whose detection trend at stages suspicious for malignancy has been increasing (center and north), in order to find the lesions at early stages, as it has recently occurred in most States of the Mexican Republic. However, it is also necessary for the number of women with a history of mammography from 40 years of age on to be increased, since this represents a useful strategy for the control and epidemiological surveillance of $\mathrm{BC}$ for reducing not only diagnoses at advanced stages, but also mortality, both considered current public health problems in Mexico.

\section{Acknowledgements}

To the women who underwent mammographic examination during the 2013-2017 five-year period, as well as to the health personnel involved in the generation and updating of the database used for this epidemiological study.

\section{Conflict of interests}

The authors declare that they have no conflicts of interest.

\section{Funding}

The authors did not receive any sponsoring to carry out this article.

\section{Ethical disclosures}

Protection of human and animal subjects. The authors declare that no experiments were performed on humans or animals for this research.

Confidentiality of data. The authors declare that they have followed the protocols of their work center on the publication of patient data.

Right to privacy and informed consent. The authors declare that no patient data appear in this article.

\section{References}

1. D'Orsi CJ, Sickles EA, Mendelson EB, Morris EA, et al. ACR BIRADS $巴$ Atlas, Breast Imaging Reporting and Data System. Reston, VA, American College of Radiology;2013.

2. Torres Tabanera M. Novedades de la 5 . $^{a}$ edición del sistema breast imaging reporting and data. Rev Senol y Patol Mamar. 2016;29(1):32-9.

3. Como entender su informe de mamograma [Internet]. American Cancer Society; 2019 [accessed January 2020]. Available at: https://www.cancer. $\mathrm{rg} / \mathrm{es} /$ cancer/cancer-de-seno/pruebas-de-deteccion-y-deteccion-temprana-del-cancer-de-seno/mamogramas/como-entender-su-informe-de-mamograma.html

4. WHO position paper on mammography screening [Internet]. World Health Organization; 2014 [accessed January 2020]. Available at: http://apps. who.int/iris/bitstream/handle/10665/137339/9789241507936_eng.pdf;jsessionid=9294040BE7603C4B8AD2F1FDECAFF350? sequence $=1$

5. Cáncer de mama: prevención y control. [Internet]. Organización Mundia de la Salud; 2020 [accessed January 2020]. Available at: https://www. who.int/topics/cancer/breastcancer/es

6. Detección temprana. Control del Cáncer: aplicación de los conocimientos. Guía de la OMS para desarrollar programas eficaces [Internet]. Organización Mundial de la Salud; 2007 [accessed January 2020]. Available at: https://www.paho.org/hq/index.php?option=com_topics and view=rdmore and cid=3681 and Itemid=40735 and lang=es

7. Norma Oficial Mexicana NOM-041-SSA2-2011, Para la prevención, diagnóstico, tratamiento, control y vigilancia epidemiológica del cáncer de mama [Internet]. Mexico: Secretaría de Salud, Diario Oficial de la Federación; 2011 [accessed January 2020]. Available at: http://dof.gob.mx/ nota_detalle.php?codigo=5194157 and fecha $=09 / 06 / 2011$

8. Encuesta Nacional de Salud y Nutrición, ENSANUT [Internet]. Cuernavaca, Mexico: Instituto Nacional de Salud Pública; 2012 [accessed January 2020]. Available at: http://ensanut.insp.mx

9. Estadísticas a propósito del día mundial de la lucha contra el cáncer de mama (19 de octubre) [Internet]. Mexico: Instituto Nacional de Estadística y Geografía; 2016 [accessed February 2020]. Available at: https:// www.ues.mx/Docs/avisos/diamundialcancerdemama.pdf

10. Cabrera-Galeana P, Soto-Perez-de-Celis E, Reynoso-Noverón N, Villarreal-Garza C, Arce-Salinas C, Matus-Santos J, et al. Clinical characteristics and outcomes of older women with breast cancer in Mexico. J Geriatr Oncol. 2018;9(6):620-5.

11. Schootman M, Jeff DB, Gillanders WE, Yan Y, Jenkins B, Aft R. Geographic clustering of adequate diagnostic follow-up after abnormal screening results for breast cancer among low-income women in Missouri. Ann Epidemiol. 2007;17(9):704-12.

12. Sirous M, Shahnani PS, Sirous A. Investigation of frequency distribution of Breast Imaging Reporting and Data System (BIRADS) classification and epidemiological factors related to breast cancer in Iran: A 7-year study (2010-2016). Adv Biomed Res. 2018;7:56.

13. Sánchez-Hernández AG, Ortiz-Mendoza CM. Frecuencia de uso de la mastografía por derechohabientes del ISSSTE en un hospital general urbano. Gac Mex Oncol. 2019;18(3):127-30.

14. Datos abiertos sobre cáncer de la mujer (SICAM). Cáncer de mama [Internet]. Mexico: Centro Nacional de Equidad de Género y Salud Reproductiva; 2020 [accessed December 2019]. Available at: http://cnegsr.salud.gob.mx

15. Camacho-Piedra C, Espíndola-Zarazúa V. Actualización de la nomenclatura BI-RADS $®$ por mastografía y ultrasonido. Rev An Radiol México. 2019;17(2):100-8

16. Cárdenas Sánchez J., Erazo Valle-Solís A., Arce-Salinas C., Bargaló-Rocha J.E., Bautista-Piña V., Cervantes-Sánchez G., et al. Consenso Mexicano sobre diagnóstico y tratamiento del cáncer mamario. Octava revisión. Colima 2019. Gac Mex Oncol. 2019;18:141-231.

17. Proyecciones de la Población de México y de las Entidades Federativas, 2016-2050 [Internet]. Mexico: Consejo Nacional de Población; 2020 [accessed December 2019]. Available at: https://datos.gob.mx/busca/dataset/proyecciones-de-la-poblacion-de-mexico-y-de-las-entidades-federativas-2016-2050

18. Auchincloss AH, Gebreab SY, Mair C, Diez Roux AV. A review of spatia methods in epidemiology, 2000-2010. Annu Rev Publ Health. 2012;33:107-22.

19. Organización Panamericana de la Salud y Consejo de Organizaciones Internacionales de las Ciencias Médicas. Pautas éticas internacionales para la investigación relacionada con la salud con seres humanos, Cuarta Edición. Geneva: Consejo de Organizaciones Internacionales de as Ciencias Médicas; 2016. 